\title{
Gubernatorial Election in Jakarta: A Political Network Analysis
}

\author{
Wahyu Prasetyawan \\ \{wprasetyawan@gmail.com \} \\ Universitas Islam Negeri Syarif Hidayatullah Jakarta, Indonesia
}

\begin{abstract}
This paper presents a network analysis to understand increasing influence of identity politics in the gubernatorial Jakarta by examining political actors who participated in that political competition. It focuses on political actors who were supported Anies Baswedan-Sandiaga Uno. It examines actors' relations. Any analysis on network relies on relations among the political actors. To understand identity politics this study adopts a network approach. It further evaluates how political actors could dictate agenda which was in line with the basic characteristics of identity politics. It is relevant here to mention that the Jakarta election took place in a political environment where conservative tendency in Islam is on the rise. This tendency should be understood as a continuation of the social and political development which took place in the late of the 1990s. This phenomenon seems to be provided a fertile ground to rise of conservative turn in the society after the fall of Suharto 1998. Furthermore, it argues that homophily, an indication to associate with those who share similar background or views, has an effect on the structure of a network, and it has the capability to set political agenda for the network. In a concrete term, it argues that the political network which supported Anies-Sandi was dominated by political actors who shared similar educational background of receiving their degree from the Saudi Arabia.
\end{abstract}

Keywords: Jakarta election, identity politics, network analysis.

\section{Introduction}

Democracy has been accepted as the institution which regulates transfer of power for many elected posts after the collapse of the New Order regime in 1998. The institutional foundation that supports democracy, such as direct election and decentralization, had been introduced aiming to circulate of power among the social forces. After more than twenty years in practice, performance of democracy requires serious examination. Satisfaction with the functioning of democracy fluctuated but has been generally positive from 2004 to 2016 hovering around 60 percent [1]. However, the nature of Indonesian democracy has been a subject of intriguing debates. There have been some serious threats to democracy in Indonesia. The challenges include potential reversal to authoritarian regime as illustrated in the 2014 presidential election if Prabowo would have been the winner [2]. As far as 2015 an evaluation concludes that Indonesia's democracy had fallen into state of stagnation [3]. There are other problems of democracy in which electoral politics is the core element: patronage distribution, including cash money, was central in the campaign strategy in the grassroots level [4] and vote buying to uncommitted voters [5]. 
This paper presents a network analysis framework to understand a rising influence of identity politics - an effort to gain votes by manipulating religious, race, or other primordial sentiments - by looking at example of the gubernatorial Jakarta election. It focuses on networks of political actors who supported Anies -Sandi. In the campaign period there were several mass rallies organized by so called conservative Muslim clerics to oppose the incumbent governor. It is quite obvious some Muslim clerics were at the front of these rallies and to a further degree defines the campaign was carried out by put emphasis on the identity of Muslim. These Muslim clerics proved their ability to reach the Muslim voters.

This paper argues on existence of a homophilous behavior - a tendency to interact with similar individuals. Halberstam and Knight [6] investigate the role of homophily in the diffusion of political information in social networks. They construct a model that calculates disproportionate exposure to like-minded information and more connections for larger groups. McPershon, Smith-Lovin and Cook [7] posit homophily as "the principle that a contact between similar people occurs at a higher rate than among dissimilar people." For them homophily suggests that social characteristics distance could be converted into network range. It is translated into the quantity of connections through which an information must travel to connect two actors.

\section{Data}

To understand political networks and homophily this study uses data from published material of both online and printed newspapers and magazines. The information from these sources were constructed to create an affiliation dataset or two-mode data. The dataset is constructed based on affiliation of an actor to organizations.

\subsection{Actors' Ideology}

This section examines actors who supported Anies-Sandi in the gubernatorial election in 2016-2017. As it will be shown, political actors who supported Anies-Sandi were varied and they have different ideology: some embrace conservative values in Islam, and other sided with the poor who was perceived as victim of the urban development. They were political parties, the clerics organization called GNPF (Movement to Defend edit of Indonesian Council of Ulama or MUI), NGO, and Saudi Arabia connection. The affiliation matrix consists of 48 actors, and they were grouped into four clusters as above. The political parties were Gerinda, PKS and PAN. There were some other politicians who were not coming from these three parties, but they supported Anies-Sandi. But, this paper concentrates on main political parties' supporters: Gerindra, PKS and PAN. These parties have different ideology. Gerindra is a secular-nationalist party, while PKS and PAN are parties that based on Islamic values. ${ }^{1}$

Muslim conservative clerics is a label given to a group of Muslim preachers/scholars who opposed liberalism, secularism and pluralism [8]. This study adopted these benchmarks to qualify whether a cleric is a conservative. If a cleric subscribes these doctrines, therefore she/he is a conservative. In addition to these qualifications, the conservative clerics also tend to disagree to have a non-Muslim governor for a region in which Muslims is a majority. NGO

${ }^{1}$ http://www.newmandala.org/mapping-indonesian-political-spectrum/, accessed 27 September 2018. 
activist refers to a group of activists who were concern over the victim of urban redevelopment including, but not only, forced eviction.

Saudi Arabia connection refers to a group of politicians and clerics who graduated from Saudi Arabian universities. Some of them became politicians, mainly is Islamist political parties, such as PKS. But there are graduates who are Islamic preachers.

To understand further connection, this paper converts two-mode data into one-mode data, that is adjacency matrix. This one-mode data is a new dataset in which a pair of actors is mentioned to be connected to the point they share affiliations. This conversion is necessary as this paper uses affiliation dataset which lacks information of a pair tie between two actors.

\section{Empirical Findings}

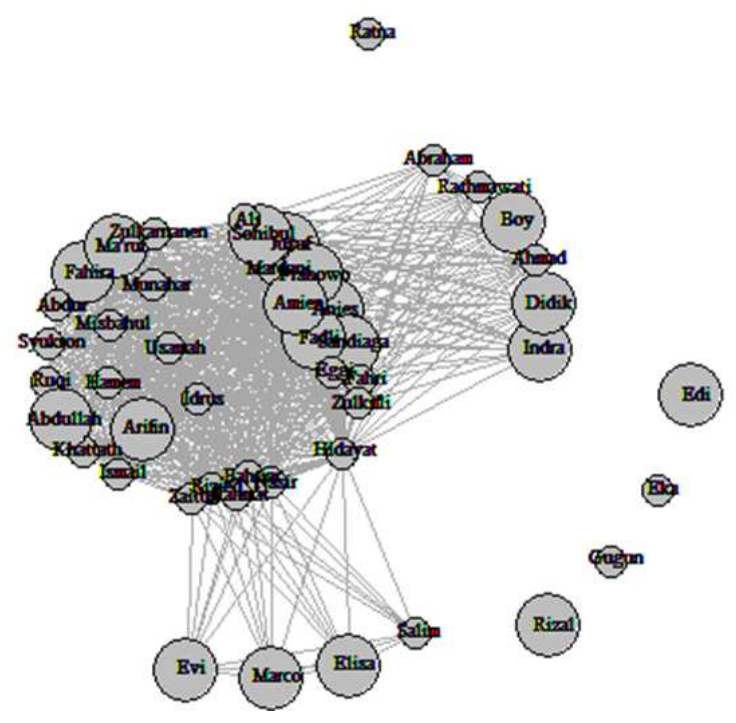

Fig. 1. Affiliation Matrix.

The dataset consisted of four groups: politicians, Muslim clerics, NGO activists, and Saudi Arabia connection. After the examination of the main supporters of Anies-Sandi, the diagram 1 shows six clusters: two groups of politicians, two clusters of Muslims conservative clerics, and two groups of NGOs. Cluster of clerics is located on the left side of the diagram and it is a big cluster. Another cluster of Muslim clerics is located in the bottom middle. This small cluster of clerics has links to NGO activist, and they may mediate the activists to both clerics and politicians. There are two cluster of politicians. One cluster located exactly in the middle of the diagram and the other on the right side. One cluster (located in the middle) is deeply connected to clerics. The other cluster, located on the left, has lesslink to clerics. This cluster only has few links to clerics, and in many cases these links were mediated by politicians in the middle of diagram.

In the diagram $1 \mathrm{NGO}$ activist divided into two clusters: one has links to clerics and politicians who were located in the bottom of diagram. It means that these links were not very strong. These activists have no direct links to the main clusters of politicians and clerics. 
Other activists have no links at all. This rather scattered activists have no links to both politicians and clerics.

The diagram points out that the networks are relatively dense in which many of the actors had links to one another. It could also be safe to mention that most of the actors have links more than one. The politicians have many links and they seemed to contact each other. Some of the politicians have links to both politicians and the clerics, while a few of the politicians have no direct links to the clerics. NGO activist were outside the networks.

Furthermore, the diagram shows that there were two main actors: Muslim conservative clerics, and politicians. These main actors were connected. If these two main actors are compared, the cluster of clerics was much bigger than the politicians. The politicians were divided into two group: those who have direct links to the clerics and those who have no no links to the clerics. The politicians who have links to the clerics served as a channel between politicians which have no direct link to clerics. Even though the clerics made up bigger cluster as compare to that of politicians, their role was not as relevant as politicians. Prabowo, Amien Rais, Zulkifli Hasan and Sohibul Iman (group B) were the main players in the network. Their relevance could be seen from visualization of diagram in which they were situated exactly in the middle. By being in the middle of networks they could channel information from both of the clerics and of other politicians such as Abraham Lunggana, Boy Sadikin, Rachmawati Sukarnoputri, and Didik Rachbini (group G). This fact underlines that both of the clerics and group $\mathrm{G}$ politicians relied on main actors in the group B. Most importantly, these politicians in the group B have direct links to the clerics. It means that they and the clerics could easily exchange information. It also emphasized that the politicians in the group B and the clerics were very well connected.

As mentioned above, the clerics make up much bigger cluster compare to other clusters. Some of the clerics with much bigger influence in the affiliation dataset were Tengku Zulkarnaen, Abdullah Gymnastiar, Arifin Ilham, Munahar Muchtar, Ismail Yusanto and Al Khatthath (henceforth group A). Even though the clerics create a much bigger cluster they have direct link to only politicians in the group B and to NGO activists (group D). The flow of information from the clerics seemed to be moved only to group B. These group of politicians and clerics received and transfer information between them.

Two clusters of NGO activits were on the periphery. One cluster of the activists (group D) have connections to the clerics who were situated in the bottom of the diagram 1 (group C). This group of clerics played much less significant role as compare to that of group A. The activists in the group D could only transfer and receive information from the group $\mathrm{C}$. They could not communicate to group A and B directly. The last cluster was activists with no ties at all to any of the other clusters (group F). Even though some of activists within group F were virtually have significant influence, however they have no links which made them less relevant. They could not transfer and receive information from other clusters. In short, they were isolated. 


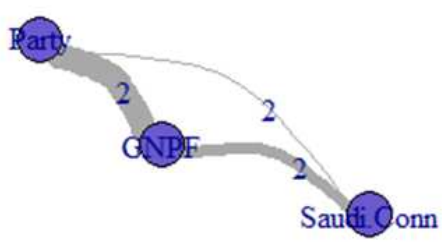

Fig. 2. Group Affiliation Matrix.

\section{Relevance of Homophily}

There were four clusters in the diagram 2. They were politicians from the political parties, a group of conservative Muslim clerics who were grouped in GNPF, Saudi Arabia alumni labelled as Saudi connection, and NGO activists. The dataset used from making the diagram 2 is similar to the one for diagram 1. But the treatment is different as for making the diagram 2, the dataset is grouped into four clusters as mentioned above.

The clerics grouped in GNPF played very important role as they served as a conduit of information between the politicians and Saudi Arabia alumni. Diagram 2 reveals only three clusters have connection: politicians, GNPF, and Saudi Arabia alumni. The cluster of activists from NGO have no links to the three clusters. It means that the cluster of activists was isolated. This finding stress importance of three groups in establishing the whole network.

The diagram 2 shows central role of actors grouped in GNPF as they connected to both politicians and Saudi Arabia alumni. It means that, to some extent, actors in GNPF served as canal of information that flow between the politicians and Saudi Arabia alumni. Does it mean that the politicians and the Saudi Arabia alumni can not directly communicate? In fact, they could communicate. However, it seemed to be more effective if their communication was mediated by the GNPF.

By considering relative relevance of the GNPF, it would be fruitful to track establishment of this loose group. The formation of the GNPF was closely related to the alleged defamation of the Qur'an by Basuki in September 2016 in the Thousand Island district, Jakarta. In part of his speech Basuki said,

"In your inner hearts, ladies and gentlemen, you may feel you cannot vote for me, because [you have been] lied to by the use of Surah al-Maidah, Verse 51. [...] So, if 
you cannot vote for me because you are afraid of being condemned to hell, you do not need to feel uneasy, because you are being fooled. It is alright." ${ }^{2}$

By stating the word "use", Basuki meant the verse had been used by some people to lie. This speech sparked a controversy and the Council of Indonesian Ulama (Majelis Ulama Indonesia, MUI) issued " a religious advisory" (and not a fatwa) in 11 October 2018 mentioned two points that: (1) Basuki had insulted the Quran, and (2) harassed the ulama, and this act had legal consequences. ${ }^{3}$ This letter signed by the MUI ${ }^{4}$. After MUI issued the edit arguing that Basuki had committed blasphemy, some of conservative Muslim clerics established a loose group which they called GNPF MUI. Even though this loose group of clerics declared by using MUI, in fact it did not have any formal link with the MUI. However, it was also a fact that one of the MUI top leader, Bachtiar Nasir, chaired the GNPF. Rizieq Syihab, from the notorious FPI, also chaired the GNPF. Zaitun Rasmin was also one of the chairs within the GNPF. In short, it should be clear that the GNPF was a loose group in which main actors comprised of conservative Muslims clerics who opposed Basuki to be reelected as governor of Jakarta.

If one looks closer to the three clusters of politicians, the GNPF, and the Saudi Arabia alumni it would be clear that GNPF connected directly to Saudi Arabia alumni. It means that some of the Saudi alumni could flow information to GNPF easily, and vice versa. The politicians have links to Saudi alumni. The possibility for politicians to have links with those Saudi alumni lied in the actors who could travel between two clusters. To underline this point, take example of three main actors within the GNPF: Bachtiar Nasir, Rizieq Syihab, Salim Segaf Al-Jufri and Zaitun Rasmin. What they do have in common? First, these actors received education in Saudi Arabia, Bachtiar and Zaitun graduated from Madinah University, while Rizieq Syihab from King Saud University. Salim Segaf Al-Jufri, who was Minister of Social Affairs under Susilo Bambang Yudhotono, graduated from Madinah University. He teaches in the LIPIA, a Saudi Arabia sponsored university in Jakarta that promoted Wahhabi ideology (Jahroni 2012). Furthermore, both Bachtiar and Zaitun received their secondary Islamic education from pesantren Gontor, Ponorogo, East Java. Hidayat Nur Wahid also received his secondary education from Gontor.

The diagram shows that the cluster of activists from NGO had no links to three important clusters. It means that the activists, as a group, did not part of the network. The activists could pass and receive any information that travel among the politicians, GNPF, and Saudi Arabia

\footnotetext{
${ }^{2}$ Jakarta Post, 12 March 2017, Ahok's Speech not Blasphemous: Expert, http://www.thejakartapost.com/news/2017/03/21/ahoks-speech-not-blasphemous-expert.html ${ }^{3}$ Detik, 11 October 2016, MUI NYatakan SIkap Soal Ucapan Ahok Terkait Maidah 51, Ini isinya, https://news.detik.com/berita/d-3318150/mui-nyatakan-sikap-soal-ucapan-ahok-terkait-al-maidah-51-iniisinya

${ }^{4}$ In 2018 Maruf Amin was selected as Joko Widodo running mate for presidential election, and Amin changed his political position to Basuki. He was very much against Basuki in the 2016-17 Jakarta election, look at https://pilpres.tempo.co/read/1115673/wawancara-majalah-tempo-blak-blakan-marufamin-soal-fatwa-ahok/full\&view=ok, downloaded 6 June 2019.

Ma'ruf Amin, saying he regretted taking part in former Jakarta governor Basuki "Ahok" Tjahaja Purnama being jailed for blasphemy, look at: https:/nasional.tempo.co/read/1163112/maruf-amin-mintamaaf-adik-ahok-tak-tahu-harus-jawab-apa, downloaded 7 June 2019. Tempo, Ma'ruf Amin minta maaf, adik Ahok tak harus jawab apa.
} 
connection. It could be interpreted, furthermore, that the activists almost played no role to set agenda. Or, perhaps, they only could push their agenda without support from the politicians, GNPF and Saudi Arabia alumni.



Fig. 3. Betweenness.

Betweenness centrality [9] is a frequency of a certain node locates along the shortest path between two other nodes. Betweenness could be understood in terms of the potential to manage flows through the network. A node (actor) with high betweenness is in a situation to intimidate the network with break of operation. In other words, a node with high betweenness could control the flow of information.

Betweenness in this analysis of social network is created from converting the affiliation dataset into an adjacency matrix. As mentioned earlier betweenness centrality measures position of nodes (actors) within a network. In other words, betweenness centrality calculates nodes' (actors') ability to receive and pass information, and even could threat the cohesiveness of a network. Betweenness centrality reflects importance of the actors' in a network.

Diagram 3 explores betweenness centrality of network from 48 actors who supported Anies-Sandi in Jakarta election in 2017. The circle reflects relative importance of actors in the network. Bigger circle reveals that the actors relatively played significant role in maintaining the network, but importantly these actors have the ability to hold or pass information in the network. The diagram points out that an actor that had bigger circle in it is situated almost in the middle of the network.

Top six actors in the network came from almost similar political and educational background. A politician place in the top of betweenness and followed by conservative Muslim clerics. Closer look at the calculation of betweenness centrality revealed that in fact there were only two actors placed at the top two: a politician and a group of clerics. The biggest blue circle belongs to Hidayat Nur Wahid a politician from PKS. Hidayat followed by other five clerics: Rizieq Syihab, Bachtiar Nasir, Zaitun Rasmin, Rahmat Labib, and Nasir Zein. These clerics scored exactly similar points and occupied in the second after Hidayat. Having mentioned that in fact there were six actors who have high leverage in the network, it could be safe to claim that they could manage flow of information in the network. Furthermore, their presence in the network made this connection solid and they could link with other members of the network easily. 
As the ranking based on betweenness centrality is crucial for understanding actors who could control the whole network. Based on the score from dataset of adjacency matrix, Hidayat had the highest score, therefore he occupied central position within the network. It seems with his position at the top allows him to control flow of information among the actors within the network. He may pass or hold information to be shared to other actors. This central position allows him to serve as a filter and the same time as conduit of information.

Closer examination of the actors in this network reveals that the next position after Hidayat and the five clerics was occupied by the politicians. The score of the politicians was half of the five clerics. This paper would argue that, to some extent, the politicians could reduce time travel of information among them only. The politicians played a much less significant role compare to that of Hidayat's and the five clerics mentioned above. On the contrary to Hidayat, the five clerics and the politicians, the NGO activists seem to be less relevant in this network. Even though the NGO activists were part of the network and, undeniably, they had some ties to other actors, in fact they were not the gatekeeper of information. These activists, for sure, had no capability to set agenda of this network.

Another NGO activist seem have no direct links to Hidayat Nur Wahid. Some of the politicians from the political parties were also located on the margin of the network. They have less role in setting the agenda of this network.

\section{Conclusion: Homophily in Jakarta Election}

Democratization in Indonesia experienced a kind of regression which caused by identity politics in Jakarta election. The rise of identity politics would likely to stain the country's electoral competition and to some degree influence the presidential election in 2019. One way to approach identity politics should be networks analysis because it can explain the dynamics of identity politics by evaluating connections among political actors. This paper adopts definition of power as ability of an actor to connect with other actors. Most importantly the networks analysis has the ability to identify prominent actors who were gatekeeper of the networks. Those gatekeepers could also formulate content of political campaign for AniesSandi which turned out to be an exploitation of identity of the voters. This analysis is very different with the writers who evaluate Jakarta gubernatorial election by employing oligarchic approach which have tendency to see wealth as determining variable. While oligarchic approach could explain dynamics of the Jakarta election, it assumed that only wealth owned by the oligarchs could determine election outcome. In reality, these oligarchs could not work alone as they had to make collaboration with other political actors from various groups. As this paper had discussed, there is another form of power that is also crucial but receive less attention.

Examination of four diagrams provide illustrations which led to better understanding to dynamics of Jakarta gubernatorial election in 2016-2017. It is necessary to remind that the network analysis here is to look links among actors in the campaign in the run up of gubernatorial election in Jakarta. The discussion above mentions that only certain actors dominate and have capability to dictate the agenda for the campaign. Even though there were many actors who came from different background in terms of ideology or political strategy, this paper finds that actors who share similar educational background have dominated the network. 
Having examined three diagrams (2 and 3), the findings were consistent to place Hidayat Nur Wahid and the five clerics as the main actors in the network. The five clerics were grouped in the GNPF. The role of GNPF in making the network solid was very difficult to deny for two reasons. The first, they were, in a sense, homogeneous in term of Islamic ideology. Second, therefore they had similar interest to disagree with non-Muslim as governor.

The GNPF played an important role to distribute information between the politicians and the Saudi alumni, and put the NGO activists on the margin. The GNPF seems able to set the agenda of the campaign for Anies-Sandi by proposing to oppose Basuki due to his background as a Christian-Chinese. By considering the role of Hidayat and the GNPF this paper contends the existence of homophily in the network that support Anies-Sandi. This finding is line to that of McPherson, Smith-Lovin and Cook [7] and Halberstam and Knight [6] who argue on the existence of homophily in the networks. One of the indications of homophily is that the clerics from GNPF and Hidayat share similar educational background of receiving higher education from university in the Saudi Arabia.

\section{References}

[1] SMRC, various survey, 204-2016

[2] E. Aspinall \& M. Mietzner, "Indonesian Politics in 2014: Democracy's Close Call", Bulletin of Indonesian Economic Studies, 50:3, 347-369, DOI: 10.1080/00074918.2014.980375, 2014

[3] A. Savirani, A and O. Törnquist, Introduction, in Savirani, A., and O. Törnquist (eds) with H. Hanif, E. Hiariej, and W. P. Samadhi, Reclaiming the State: Overcoming Problems of Democracy in Post-Soeharto Indonesia, Yogyakarta: PolGov and PCD Press, 2015

[4] E. Aspinall and Mada Sukmajati (eds), Electoral Dynamics in Indonesia: Money Politics, Patronage and Clientelism at the Grassroots, Singapore: National University of Singapore Press, 2016

[5] Burhanuddin Muhtadi, Buying Votes in Indonesia: Partisan, Personal Networks, and Winning Margin, Dissertation at Australian National University, 2018

[6] Y. Halberstam and Brian Knight, "Homophily, Group Size, and the Diffusion of Political Information Social Networks: Evidence from Twitter", Journal of Public Economics 143: 73-88, 2016

[7] Miller McPershon, Smith-Lovin, Lynn, and Cook, James, , Birds of a feather: homophily in social networks, Annual Review of Sociology (27), pp-415-444, 2001

[8] C. Kersten, Islam in Indonesia: The Contest for Society, Ideas and Values, Oxford University Press, Oxford, 2016

[9] Linton C. Freeman, "Centrality in Social Networks Conceptual Clarification" in Social Networks, Vol 1 (3), pp.215-239, 1979 